\title{
ALTERNATIVE DISPUTE RESOLUTION: USE AND ABUSE OF INFORMATION AND SPECIALIZED KNOWLEDGE
}

\section{JUDITH A. SNIDER and C. KEMM YATES*}

The authors examine the subject of Alternative Dispute Resolution ("ADR") with a focus on the issue of specialized knowledge and its use in two particular spheres of ADR: regulatory tribunals and arbitration. The authors define "specialized knowledge" and compare it to the concept of evidence in order to determine whether it is evidence which can be relied upon by regulators and arbitrators in the context of their ADR decision-making. The relationship between specialized knowledge and the rules of natural justice is explored - in particular, the audi alteram partem rule and the rule against bias. The authors conclude by suggesting guidelines to be used by arbitrators and regulatory tribunals in adjudicating on matters before them in order to avoid challenges, by judicial review, to their decisions on the basis of misuse or "abuse" of their specialized knowledge.

\section{TABLE OF CONTENTS}

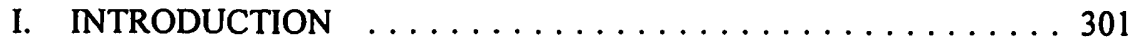

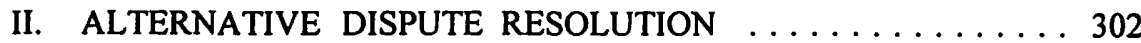

III. SPECIALIZED KNOWLEDGE $\ldots \ldots \ldots \ldots \ldots \ldots \ldots \ldots \ldots 303$

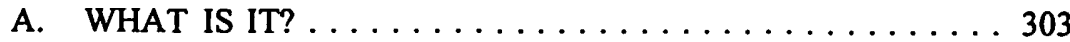

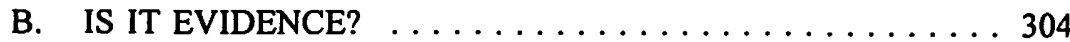

C. THE RULES OF NATURAL JUSTICE

AND SPECIALIZED KNOWLEDGE $\ldots \ldots \ldots \ldots \ldots \ldots 306$

IV. REGULATORY TRIBUNALS $\ldots \ldots \ldots \ldots \ldots \ldots \ldots \ldots$

A. WHAT ARE THEY? ................. 309

B. WHAT KNOWLEDGE CAN BE RELIED

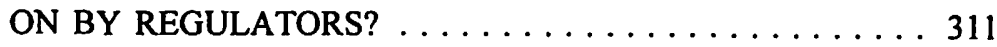

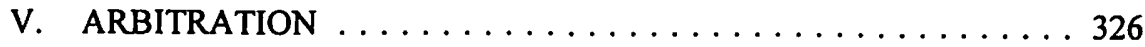

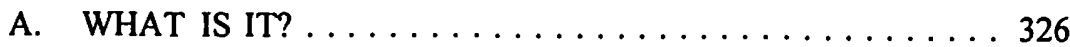

B. WHAT KNOWLEDGE CAN BE RELIED

ON BY ARBITRATORS?

VI. SUGGESTED GUIDELINES FOR ADR

ADJUDICATORS $\ldots \ldots \ldots \ldots \ldots \ldots \ldots \ldots \ldots \ldots \ldots \ldots \ldots \ldots$

\section{INTRODUCTION}

It is increasingly fashionable to pay homage to alternative dispute resolution. Its acronym, ADR, is in the vocabulary of virtually every participant in the petroleum industry. Conventional wisdom is that ADR is a new and effective method to resolve issues more quickly, more efficiently and less expensively than would be possible using

Judith A. Snider is General Counsel of the National Energy Board of Canada. C. Kemm Yates is a partner of the law firm of Milner Fenerty of Calgary and Edmonton. The assistance of Susan M. Wakil of Milner Fenerty is gratefully acknowledged. The views expressed are solely those of the authors and do not represent the positions of the National Energy Board or any client of Milner Fenerty. 
the existing judicial system. Conventional wisdom is often misleading, though, and in the case of ADR there are two fundamental misconceptions. First, ADR is not new. The desire for alternative and more effective methods of dispute resolution generated the original concept of arbitration and gave rise to regulatory tribunals in the nineteenth century. Second, ADR is no panacea. Some of the attributes of ADR that can make it more efficient than the civil courts are the same attributes that raise issues of law and equity that are difficult to resolve and are fraught with risk of judicial review. For example, the particular knowledge and expertise that is required of arbitrators and regulators to decide technically complex issues may void their decisions for breach of the rules of natural justice. Adjudicators must walk a fine line between the proper use and the reviewable abuse of information and specialized knowledge. Review and analysis of the present state of the law suggest guidelines for the conduct of adjudicators and the parties who use them.

\section{ALTERNATIVE DISPUTE RESOLUTION}

There are three primary methods of resolving disputes - negotiation, mediation and adjudication. Negotiation essentially involves communication between the parties to a dispute with respect to the form of joint actions that they might take to resolve the conflict between them. Mediation involves the intervention into a dispute of an acceptable, impartial and neutral third party, having no decision-making power, to assist the disputing parties to voluntarily reach their own mutually acceptable settlement. Adjudication involves the presenting of evidence and arguments to a neutral third party who has the power to make a binding decision. '

The civil court system arose as a method of dispute adjudication. It developed its own excesses that resulted in higher costs, undue delays and consequent denial of access to justice. It became incapable of efficiently resolving technically complex or specialized issues. The result was that parties looked for alternative methods of adjudication. One alternative that developed was arbitration; another involved regulatory tribunals.

Arbitration is, essentially, a non-judicial proceeding in which the parties to a dispute submit their issue to an impartial person or group of persons for resolution. It has many advantages over formal adjudication by the civil courts. It is private and convenient, has reduced formality, involves flexibility in awards, utilizes an "expert" decision maker chosen by the parties, and potentially avoids the costs and delays of litigation. ${ }^{2}$ It has disadvantages as well. The consensual nature of the proceeding means that it can be sabotaged by a party who sees its interests served by delay. The benefits of speed and reduced cost can rapidly evaporate in interlocutory proceedings and court applications.

The Canadian Bar Association Task Force, Report of the Canadian Bar Association Task Force on Alternative Dispute Resolution: A Canadian Perspective (Ottawa: Canadian Bar Association, 1989) (Chair: B.J. Thompson) at 5-6 [hereinafter CBA Task Force Report on ADR]. 
Regulatory tribunals do not leap into many minds when the topic of ADR is raised. Perhaps this oversight stems from the fact that the tribunals have adjudicative responsibilities that are established by statute and restricted to specialized areas of expertise. It may also be that the ambit of responsibility of tribunals is seen as being limited to public interest disputes involving citizens and levels of government. It is true that agencies such as the National Energy Board of Canada ("NEB") are charged with the responsibility of protection of the public interest, but it is also true that the public disputes that are adjudicated by such boards involve the private interests of all the affected parties. The fact is that the statutory establishment of regulatory tribunals moved certain types of specialized disputes from the civil judicial forum to ADR where they have been resolved by "expert" adjudicators for decades.

Members of both regulatory tribunals and arbitration panels make decisions regarding the rights of parties. As such, the principles of natural justice require the decision makers to act in a fair manner in dealing with matters before them. Natural justice has been described as "what a reasonable man would regard as fair procedure in particular circumstances." ${ }^{3}$ Jones \& de Villars, in their text Principles of Administrative Law, summarize the requirements:

The principles of natural justice have been applied by the courts for many years to determine whether a delegate has adopted a fair procedure in the exercise of his statutory powers. Natural justice and procedural faimess are presumed by the common law to be implied limitations on the exercise of delegated power. The courts have adopted these rules from their own procedures, and have applied them to administrators generally, whether or not quasi-judicial functions are involved. ${ }^{4}$

While arbitrators are not exactly "delegates" in the sense used by Jones \& de Villars, their functions should bring them within the application of the same basic "fairness" principles as tribunal members.

The precise scope and extent of the principles of natural justice have never been fully defined. It is probably impossible to do so. Two fundamental components have, however, been recognized: audi alteram partem ("no man to be condemned unheard") and nemo judex in sua causa debet esse ("no man be judge in his own cause," more usually referred to as the rule against bias). It is within the scope of these two principles that an examination of specialized knowledge of decision makers in the ADR process must be conducted.

\section{SPECIALIZED KNOWLEDGE}

\section{A. WHAT IS IT?}

What is this "specialized knowledge" that is possessed by the adjudicators in ADR? First, every member of a regulatory tribunal and arbitration panel brings to his position 
knowledge related to the general mandate of the tribunal or arbitration panel. A member of the NEB, for example, may have been an executive with a gas utility with years of experience in the area of gas contracting practices or may have been a civil servant in the employ of an energy ministry of the federal government with broad understanding of the political climate related to national and international energy issues. Similarly, an arbitrator may have been chosen for a dispute over the particular terms of a gas sales contract because of his experience with negotiating or litigating such contracts.

The other category of "specialized knowledge" is that which is acquired by the adjudicator during his tenure as a decision-maker. Most tribunal members are appointed for a term certain, rather than for the hearing of a particular matter. During the term of appointment, the member continues to read, meet, attend conferences, discuss and otherwise utilize means by which he can increase his specialized knowledge and, hence, his effectiveness as a board member. While arbitrations are intended to be swift, they can in fact take extensive time during which the arbitrator may continue to add to his knowledge base.

Within the context of this knowledge, there will be information that the decisionmaker possesses that is of a general nature (for example, understanding of the industry which is being regulated or which is the subject of the arbitration). There will also be knowledge that is more specific to the application or arbitration before him (for example, knowledge of previous safety or environmental problems faced by a pipeline company or information on the contract price of gas in a similar gas sales contract).

Two fundamental questions arise:

(1) Does any of this "specialized knowledge" comprise "evidence"?

(2) How do the principles of natural justice relate to this "specialized knowledge"?

\section{B. IS IT EVIDENCE?}

There are myriad definitions of "evidence". Black's Law Dictionary states:

All the means by which any alleged matter of fact, the truth of which is submitted to investigation, is established or disproved. Any matter of fact, the effect, tendency, or design of which is to produce in the mind a persuasion of the existence or nonexistence of some matter of fact. That which demonstrates, makes clear, or ascertains the truth of the very fact or point in issue, either on the one side or on the other. That which tends to produce conviction in the mind as to existence of a fact. The means sanctioned by law of ascertaining in a judicial proceeding the truth respecting a question of fact. ${ }^{5}$

The Canadian Law Dictionary contains a similar definition: 
All the means by which any alleged matter of fact, the truth of which is submitted to investigation at judicial trial is established or disproved. Evidence includes testimony of witnesses, introduction of records, documents, exhibits, objects, photographs, drawings, offered for the purpose of inducing belief in the party's contention by the trier of fact. An allegation or conjecture is not itself evidence. ${ }^{6}$

The authors of Phipson on Evidence offer the following definition:

Evidence, as used in judicial proceedings, has several meanings. The two main senses of the word are: first, the means, apart from argument and inference, whereby the court is informed as to the issues of fact as ascertained by the pleadings; secondly, the subject-matter of such means. The word is also used to denote that some fact may be admitted as proof and also in some cases that some fact has relevance to the issues of fact. In a real sense evidence is that which may be placed before the court in order that it may decide the issues of fact.... Evidence ... [in this] sense, means the testimony, whether oral, documentary or real, which may be legally received in order to prove or disprove some fact in dispute.

This passage received judicial endorsement from the Manitoba Court of Appeal in $R$. v. Zeolkowski. ${ }^{8}$ It was put more succinctly by the Alberta Supreme Court in $R$. v. Whittaker:

[A]ll the legal means, exclusive of mere argument, which tend to prove or disprove any matter or fact, the truth of which is submitted to judicial investigation.

[There are] many illustrations of evidence which come not under the head of either testimony or documents....9

It is clear from the dictionaries, texts and cases that "evidence" encompasses all materials which may influence the decision in a particular case. It includes the words and materials offered by the parties, but also extends to include other matters which tend to sway or persuade the adjudicator to make a certain finding of fact or decide in favour of one side or the other. Conversely, matters arising outside the hearing process which have not influenced or persuaded the judge in rendering a decision in a particular case are not evidence, nor is an expert arbitrator's general knowledge of the circumstances forming the background to a particular case. The "specialized knowledge" which such an arbitrator uses in interpreting the case before him is not evidence, but is rather a means of considering, weighing and assessing the evidence before him. ${ }^{10}$

R.S. Vasan, ed., The Canadian Law Dictionary (Toronto: Law and Business Publications, 1980). M.N. Howard, P. Crane \& D.A. Hochberg, Phipson on Evidence, 14th ed. (London: Sweet \& Maxwell, 1990) at 2, para. 1-03. [1987] 3 W.W.R. 739 at 745,39 D.L.R. (4th) 45, 33 C.C.C. (3d) 231, 46 Man. R. (2d) 40 rev'd on other grounds [1989] 1 S.C.R. 1378. 


\section{THE RULES OF NATURAL JUSTICE AND SPECIALIZED KNOWLEDGE}

\section{Audi Alteram Partem}

The audi alteram partem rule means that all parties to the ADR process must be aware of all evidence that is used by the adjudicator in making a decision. Failure to place all evidence on the record, and to provide parties with an opportunity to address such evidence, may invalidate a decision. While complexities arise with respect to the definition of "evidence" and the manner in which the information is placed before the parties, the applicability of this simple proposition to administrative decisions is not in doubt.

When a decision-maker or one of his staff obtains evidence (as distinct from preexisting general knowledge), that information should be disclosed, as should any information obtained by a tribunal through its own investigations." At a minimum, any supplemental information obtained outside the material submitted in evidence which is relied upon must be of a public nature or of a kind that was readily available to the parties prior to the hearing. ${ }^{12}$ If additional information is acquired after the hearing has closed but before a decision is rendered, the information should be disclosed to the parties and the hearing should be reopened. ${ }^{13}$

The leading case regarding the necessity of hearing evidence with all participants present is Kane v. Board of Governors of the University of British Columbia. ${ }^{14}$ The case involved the dismissal of Dr. Kane by the president of the university. Kane then appealed to the Board of Governors. After the Board of Governors concluded its hearing, the university president answered questions by board members regarding the dismissal. Neither Dr. Kane nor his counsel were present when the president related these facts, nor were they able to cross-examine the president on the additional evidence provided. The Supreme Court of Canada held that allowing the president to give evidence during the subsequent session in Dr. Kane's absence amounted to a

Canadian Pacific Ltd. v. B.C. Forest Products Ltd., [1981] 2 F.C. 745 at 757, 34 N.R. 209 at 221 (F.C.A.), leave to appeal to S.C.C. refused (1980), 34 N.R. 349; Re Frank Bros. Lid. v. Hamilton Police Commrs., [1967] 63 D.L.R. (2d). 3092 O.R. 284 (Ont. H.C.J.) [hereinatter Re Frank Bros. LId.] (driving by the applicant's premises in connection with a previous proceeding and subsequently relying upon this information to determine the type of business being carried on). In the former case, after a hearing to determine the validity of railway freight increases, the Canadian Transportation Commission conducted its own investigation and obtained information which was not made available to the railways before the Commission rendered its decision. The Federal Court of Appeal set aside the decision on the basis that the railways were denied natural justice in not being afforded the opportunity to respond to the new information.

For example, no breaches of natural justice occurred in $R$. v. Schiff, ex parte Ottawa Civic Hospital Trustees, [1970] 13 D.L.R. (3d) 304, 3 O.R. 476 (C.A.) (in relation to public statistics) [hereinafter Schiff cited to D.L.R.] or Lazar v. Association of Professional Engineers of Man. (1971), 23 D.L.R. (3d) 614, [1971] 5 W.W.R. 614 (Man. Q.B.) (in relation to a textbook). Kane v. Board of Governors of the Univ. of B.C., [1980] I S.C.R. 1105 at 1117 [hereinafter Kane]; Canadian Pacific Ltd. v. B.C. Forest Products Ltd., supra note 11. 
breach of the principles of natural justice and the audi alteram partem rule. In the process of stating a number of propositions of law, Dickson J. (for the majority) stated:

As a constituent of the autonomy it enjoys, the tribunal must observe natural justice which ... is only "fair play in action"... To abrogate the rules of natural justice, express language or necessary implication must be found in the statutory instrument.

The tribunal must listen fairly to both sides, giving the parties to the controversy a fair opportunity "for correcting or contradicting any relevant statement prejudicial to their views"

It is a cardinal principle of our law that, unless expressly or by necessary implication, empowered to act ex parte, an appellante authority must not hold private interviews with witnesses ... or, a fortiori. hear evidence in the absence of a party whose conduct is impugned and under scrutiny. Such party must, in the words of Lord Denning in Kanda v. Government of the Federation of Malaya [[1962] A.C. 322], at 337, "...know the case which is made against him. He must know what evidence has been given and what statements have been made affecting him: and then he must be given a fair opportunity to correct or contradict them.... Whoever is to adjudicate must not hear evidence or receive representations from one side behind the back of the other...."1s

He then continued:

In ... $R$ v. Deputy Industrial Injuries Commissioner, Ex p. Jones [[1962] 2 Q.B. 677], the tribunal received evidence which was both fresh and highly prejudicial to the applicant's position. The case at bar cannot be put so strongly, but the principle to be applied is the same. Lord Parker C.J., in granting the order for certiorari, stated that a tribunal is not entilled to continue privately to obtain evidence between the end of a hearing and the reaching of decision "without notifying the parties thereafter of the advice or information received, so as to give the parties an opportunity of having a further hearing if need be, or, at any rate, commenting on the information and making their submissions thereon" ( $\mathrm{p}$. 686).

[E]ach party to a hearing is entitled to be informed of, and to make representations, with respect to evidence which affected the disposition of the case....

The court will not inquire whether the evidence did work to the prejudice of one of the parties; it is sufficient if it might have done so. 
Applying the foregoing principles, I think this appeal must succeed. The Board was aware of the possibly anomalous position of the President during the after dinner deliberations.... [D]espite the care with which the appeal was conducted, the Board, as appears to be the case, found that it needed additional, "necessary" facts before reaching a decision, and the President furnished those facts...

The Board was under an obligation to postpone further consideration of the matter until such time as Dr. Kane might be present and hear the additional facts adduced; at the very least the Board should have made Dr. Kane aware of those facts and afforded him a real and effective opportunity to correct or meet any adverse statement made. In the event, the Board followed neither course. The Board heard the further facts, deliberated, and ruled against Dr. Kane. In so doing, it made a fundamental error. The danger against which the Courts must be on guard is the possibility that further information could have been put before the Board for its consideration which affected the disposition of the appeal.... ${ }^{16}$

\section{Rule Against Bias}

Courts have rightly held members of administrative tribunals to high standards of impartiality. The law demands more of quasi-judicial decision-makers than a mere avoidance of pecuniary interest in the matter before them: there must be no reasonable apprehension of bias. An example of this high standard is seen in the case of Spence v. Spencer and Prince Albert Board of Police Commissioners, ${ }^{17}$ where a police officer was dismissed following a hearing. Prior to the hearing, a witness had met privately with the chairman of the Board of Police Commissioners to discuss the charges against the officer. The Saskatchewan Court of Appeal allowed the officer's appeal and quashed the commission's orders, stating:

The law is well settled that a quasi-judicial tribunal like the Police Commissioners is subject to the rules of natural justice which are, after all only "fair play in action"... The rule against bias is one of the most fundamental elements of natural justice. A person accused is entitled to have his cause determined by an impartial tribunal which is untainted with the knowledge of facts or with a predisposition to a particular point of view which might affect the result. The policy underlying this principle is that justice must not only be done but must manifestly and undoubtedly be seen to be done.... A breach of the rule against bias will generally result in the statutory delegated authority losing jurisdiction and will render the administrative action void and subject to judicial review. The respondent submits that there is no real or apprehended bias by reason that the chairman did not discuss "specific" allegations against the appellant.

It is not necessary to demonstrate that the chairman was actually biased. The test is whether there was a reasonable apprehension of bias.... ${ }^{18}$

Ibid. at 1115-17 [emphasis added].

17 (1987), 53 Sask. R. 35, 25 Admin. L.R. 90, leave to appeal to S.C.C. refused (1987), 80 N.R. 316 (note), 58 Sask. R. 80 (note) [hereinafter Spence cited to Sask. R.]. 
Spence and other cases make it clear that the rule against bias applies to ADR decision makers. The very expertise that makes an adjudicator an effective tribunal member or arbitrator may disqualify him from putting that expertise into practice. That is especially so for technical boards or arbitrators, where adjudicators often come from the industry which is the subject dealt with by the tribunal.

\section{REGULATORY TRIBUNALS}

\section{A. WHAT ARE THEY?}

It is generally acknowledged that the reasons for the creation of regulatory tribunals included the need to address concerns over the inappropriateness of having courts decide technically complex issues in an increasingly complicated society, the perceived necessity for expertise in dealing with complex issues, and a desire to increase the speed of administration. It was felt that judges, trained to be legal generalists, would lack the expertise and knowledge to determine technical questions with the efficiency required to meet commercial needs. The result was establishment of a "quasi-judicial" system of administrative tribunals, clearly a form of ADR.

Three other reasons for the creation of regulatory agencies in the twentieth century are often cited:

(1) to reduce the workload of increasingly overburdened legislators;

(2) to develop cumulative technical expertise through specialization; and

(3) to de-politicize the regulatory process, thereby permitting delegation of politically unpopular decisions. ${ }^{19}$

In the words of the CBA Task Force Report on Tribunals,

[T] he very reason for establishing independent agencies [in] the first place ... is to create an independent, non-political decision-maker with specialized knowledge and experience and the opportunity to base their decisions on the results of complete, fair and open hearings. ${ }^{20}$

19 A.J. Roman, "Regulatory Law and Procedure" in G.B. Doern, ed., The Regulatory Process in Canada (Toronto: Macmillan, 1978) 68 at 73-74; The Canadian Bar Association Task Force, The Independence of Federal Administrative Tribunals and Agencies in Canada (Ottawa: The Canadian Bar Association, 1990) (Chair: E. Ratushny) at 135-36 (hereinafter CBA Task Force Report on Tribunals]; D.A. Townsend, "The Growing Irrelevance of Judicial Review: Administrative Law and the Entrepreneurial Culture" 6 C.J.A.L.P. 79 at 93; Ontario, Directions: Review of Ontario's Regulatory Agencies (Overview) (Toronto: Queen's Printer, 1989) at 4-5. In Alberta, the Special Committee on Boards and Tribunals, Report of the Special Committee on Boards and Tribunals to the Legislative Assembly of Alberta (Edmonton: Legislative Assembly of Alberta, 1965) at 76 [hereinafter Clement Report] also implicilly recognized expertise of tribunal members as one reason for establishing administrative tribunals.

CBA Task Force Report on Tribunals, ibid. at 143. 
However, specialization and expertise were not the only reasons for establishing regulatory tribunals for, if they were, the process would have been entrusted to bureaucrats working within government departments. Regulatory tribunals were established in order to ensure that decisions which affect Canadian citizens occur in a public forum, usually in the context of a public hearing. It is therefore central to the concept of regulatory tribunals that such tribunals, which render decisions of great national importance, do so in ways which are public and based upon evidence which is publicly accessible.

The history of the creation of the NEB is illustrative. In 1957, the Gordon Royal Commission on Canada's Economic Prospects ${ }^{21}$ commented at length on the extent and importance of the nation's energy resources. After observing that information on these resources was inadequate and that Canadian producers had a weak bargaining position, the Gordon Commission recommended that a comprehensive energy policy be developed and that a national energy authority be formed to advise the government "on all matters connected with the long-term requirements for energy in its various forms and in different parts of Canada." It suggested that this agency should have the authority to approve all contracts for the export of gas, oil and power. In their conclusions regarding the future of Canada's energy industry, the commissioners stated:

[B]y and large what we foresee is a less specialized Canadian economy as a result of developments in our energy resources and in the energy resources available elsewhere throughout the world. Energy costs are coming together and energy is being diffused more widely, almost as it were, in accordance with the Second Law of Thermo-dynamics. To pluck new economic advantages from this new situation will require initiative and brains and technical skill of a high order. ${ }^{22}$

Before implementing these recommendations, the government of the day appointed the Borden Royal Commission to recommend policies that would best serve the national interest in the export of energy and energy resources. The Borden Commission was specifically asked to make recommendations concerning the extent of authority which should be conferred on a national energy board to administer energy policy, as well as the nature of the administration and procedures that should be established for such a board. ${ }^{23}$ The commission report contained extensive recommendations concerning the Chapter 7 [hereinafter Gordon Commission]; see also A. Lucas \& T. Bell, The National Energy Board: Policy, Procedure and Practice (Ottawa: Law Reform Commission, 1977) at 6-7. For a more comprehensive historical background of the NEB and ERCB, see D. H. Breen, Alberta's Petroleum Industry and the Conservation Board (Edmonton: University of Alberta Press, 1993); I. McDougall, "The Canadian National Energy Board: Economic Jurisdiction in the National Interest or Symbolic Reassurance?" (1973) 11 Alta. L. Rev. 327 at 329-38; A. Lucas, "The National Energy Board" in Doern, ed., supra note 19 at 259n; B. Fisher, "The Role of the National Energy Board in Controlling the Export of Natural Gas from Canada" (1971) 9 Osgoode Hall L. J. 553 at 554-58; W. Kilborn, Pipeline: TransCanada and the Great Debate, History of Business and Politics (Toronto: Clarke, Irwin, 1970).

22 Gordon Commission, ibid. 148 [emphasis added].

23 Hon. Gordon Churchill, Minister of Trade and Commerce, in Debales (18 May 1959) at 3766, quoting Order-in-Council of October 15, 1957. 
formation of the NEB and outlined a number of highly specialized functions which it envisioned would be carried out by the new board. ${ }^{24}$ Implicit in its recommendations was the idea that members of the NEB would have a significant degree of expertise in the energy field.

It is clear that an important rationale for establishing the NEB was to provide a body with members who were appointed for their expert knowledge to adjudicate on energy policy in a way which would achieve administrative efficiency.

\section{B. WHAT KNOWLEDGE CAN BE RELIED ON BY REGULATORS?}

\section{Agency Expertise}

An examination of the use of information and specialized knowledge within the setting of administrative tribunals is assisted by an understanding of how a typical tribunal operates and, in particular, how the expertise of the agency is used. Again, the NEB is illustrative.

Board members are, naturally, the most important players in the piece. Generally appointed for terms certain (NEB members serve for terms of seven years), they normally bring some area of expertise to their positions. During their terms, they will apply their pre-existing knowledge to the decision-making processes of the tribunal. In addition, they will enhance their expertise through a number of means: reading, briefings by staff, sharing of knowledge among members, attendance at courses and seminars, and meetings (both formal and informal) with the industry which the tribunal regulates. In the course of a particular hearing, knowledge related to the specific matters before the tribunal and on which the tribunal will rely in reaching its decision is acquired more formally through the record. After a proceeding, however, that caserelated information becomes part of the overall knowledge of the tribunal member. It is expected that tribunal members become more effective as their knowledge bases increase through their tenures.

Most tribunals employ staff to help carry out their mandates. The NEB staff complement is about 300 , organized around the statutory responsibilities of the board. The main function of staff is to advise tribunal members. Accordingly, staff usually bring a high level of expertise in specific areas. During a public hearing, staff assist with organization and review of the evidence, provides briefings to panel members on technical matters and makes recommendations regarding the decisions to be made by the board members. This process greatly contributes to the efficiency of the hearing process.

When an applicant appears in the oral portion of a hearing, there is no requirement to build a record "from the bottom up". Parties to a proceeding commence their 
submissions with the assumption that the tribunal members have, either through their own expertise or through staff briefings, an understanding of the fundamentals underlying the specific subject matter of the hearing. This makes the conduct of written proceedings possible. It clearly shortens the time required for oral hearings. It allows a tribunal to consider uncontested matters without any hearings whatsoever. The tribunal can have an ongoing knowledge of the "public interest" without re-establishing the meaning of each technical term used in an application for each matter before it.

Against this backdrop of how, typically, tribunals go about carrying out their mandate, it remains to examine the interplay among the legal requirements for adherence to the principles of natural justice, the efficient completion of matters before the boards and the use by tribunals of specialized knowledge.

\section{Prior Experience and Associations}

As indicated, tribunal members often bring to their positions expertise acquired from past associations with the industry which they now must regulate. These past associations often raise the question of whether the regulator is unbiased. A number of cases have considered the nature of apprehension of bias in the context of such situations.

In the leading case on bias, Committee for Justice \& Liberty v. National Energy Board, ${ }^{25}$ the NEB sought a judicial determination of whether it would err if it allowed its Chairman, Marshall Crowe, to sit on a particular hearing. The hearing in issue involved competing applications for approval to construct a pipeline to bring natural gas from the Canadian Arctic to southern markets. Prior to Mr. Crowe's appointment to the NEB, he had been president of a corporation that was actively involved in the activities of one of the applicants in respect to the very pipeline over which he proposed to adjudicate as Chairman of the NEB. The Supreme Court of Canada found a reasonable apprehension of bias and disqualified Mr. Crowe from presiding over the case. Chief Justice Laskin noted that it is of particular importance that the NEB comply with the rules of natural justice, as its mandate is to act in the public interest:

This test is grounded in a firm concern that there be no lack of public confidence in the impartiality of adjudicative agencies, and I think that emphasis is lent to this concern in the present case by the fact that the National Energy Board is enjoined to have regard for the public interest. ${ }^{26}$

He suggested that board members should conduct themselves in a manner similar to judges:

What must be kept in mind here is that we are concerned with a s.44 application in respect of which, in my opinion, the Board's function is quasi-judicial or, at least, is a function which it must discharge in accordance with rules of natural justice, not necessarily the full range of such rules that would apply 
to a Court (although I note that the Board is a court of record under s.10 of its Act) but certainly to a degree that would reflect integrity of its proceedings and impartiality in the conduct of those proceedings.... ${ }^{27}$

He stated further:

When the concern is, as here, that there be no prejudgment of issues (and certainly no predetermination) relating not only to whether a particular application for a pipeline will succeed but also to whether any pipeline will be approved, the participation of Mr. Crowe in the discussions and decisions leading to the application made by Canadian Arctic Gas Pipeline Limited for a certificate of public convenience and necessity, in my opinion, cannot but give rise to a reasonable apprehension, which reasonably well-informed persons could properly have, of a biased appraisal and judgment of the issues to be determined on a s. 44 application. ${ }^{28}$

In a more recent case, Bennett v. British Columbia (Superintendent of Brokers), ${ }^{29}$ the British Columbia Court of Appeal disqualified a person from an inquiry panel of the British Columbia Securities Commission on the basis of apprehension of bias. The panel was struck to inquire into the actions of the majority shareholder, chairman and president of a company. The panel included a director of a corporate competitor of that company. The question was:

Would a reasonable person think it just that a director of a company in a certain industry should sit on such an inquiry as this into the conduct of a director of another company in the same industry, if the result of that inquiry might be that the director whose conduct is in issue and who is of substantial importance to his own company, may be barred from the management of his company and that company may be seriously harmed by his non-participation in the management? ${ }^{30}$

Undoubtedly, a critical factor in this case was the fact that the panel member continued as a director of his own corporation during his tenure as commissioner. The situation may have been different if his directorship had terminated sometime prior to his appointment as a commissioner.

While passage of time did not heal the apprehension of bias for Mr. Crowe, another NEB-related case shows that the apprehension of bias of a tribunal member can be extinguished over time. In Flamborough v. National Energy Board, ${ }^{31}$ the Federal Court of Appeal considered the case of NEB member William G. Stewart, who had retired from Union Gas Limited as president in 1979 after twenty-four years of employment. The policy witness for an applicant to the NEB was a person whose previous employment, from 1960 to 1981, had been with Union Gas. An intervenor sought the disqualification of Mr. Stewart from the panel hearing the application on the 
basis that the previous association of the two men was sufficient to raise an apprehension of bias. In dismissing this allegation, the Court stated:

A prior business association is not, per se, a basis upon which to find a reasonable apprehension of bias, even when it was an association with an organization having a direct interest in the matter to be decided, unless the tribunal member had been involved with the organization when it made its decisions regarding that matter. That was the dictum of the Supreme Court of Canada in the Croue case. It follows that a prior business association with a witness in a business organization when none of them: tribunal member, witness or organization, had any interest whatsoever in the matter to be decided, cannot be accepted as a basis for a reasonable apprehension of bias on application of the objective test stated. ${ }^{32}$

This issue can be summarized by saying that courts are prepared to accept, and even endorse, the use- of an adjudicator with specialized knowledge acquired through previous activities, provided that:

(i) the business association is not continuing; and

(ii) during prior business associations, the adjudicator was not involved with the matter which is now before the tribunal.

\section{Acquisition of Specialized Knowledge During Tenure}

The acquisition of specialized knowledge does not cease upon appointment of a tribunal member to a board. It is often after being named to a tribunal that the education and specialization become critical to the performance of the members' duties. This process is often accomplished through industry contacts. A fine line exists between maintaining contacts and attending meetings and becoming susceptible to an allegation of apprehension of bias. Although the case of CNG Transmission Corp. v. National Energy Board ${ }^{33}$ deals with a meeting held during the course of an application rather than a meeting held to acquire or enhance general knowledge, it clearly highlights some of the dangers of meetings between tribunal members and parties involved in a matter before the tribunal.

In $C N G$ v. $N E B$, a reasonable apprehension of bias was found to exist because one side to the dispute conducted private meetings with NEB board members. The NEB had rejected an application by TransCanada PipeLines Limited to construct a pipeline extension. Before the decision was issued, parties supporting the application arranged a private meeting with two members of the board (including the chairman) and a member of the NEB legal staff, although the meeting itself was postponed until after the actual decision was issued. At the meeting, representations were made on aspects of the case and arguments were advanced to encourage the NEB to review its decision. It was then agreed that although the NEB itself would not initiate a review, the 
corporations in attendance at the meeting could submit a review application and request that the NEB expedite the review process. When CNG received a copy of the review application that was subsequently filed, its counsel wrote to the NEB to request an opportunity to address the issue of whether a review was warranted. The NEB, without responding to the CNG request, advised that it had been "persuaded by the applicants' arguments" that a review was justified and that it would expedite the review process in this particular case.

CNG applied to the Federal Court for certiorari to quash the decision to review on the basis that the meeting with the pipeline representatives in the absence of CNG raised a reasonable apprehension of bias. Cullen $\mathrm{J}$. held that the rules of faimess applied to the NEB's decision to review, and that those rules had been breached. He stated:

With respect to the question of reasonable apprehension of bias, there is no dispute that the issue is not whether the members named are actually biased (and counsel for the applicant made it quite clear they were not making such an allegation) but whether the circumstances could properly cause a reasonably well-informed person to have a reasonable apprehension of a biased appraisal or judgment by the member, however unconscious or unintentional it might be. ${ }^{34}$

While finding that this particular meeting was fatal to the NEB decision to review, the Court acknowledged that meetings with industry are possible:

\begin{abstract}
After reviewing the arguments, I agree with the respondents that NEB members should not be precluded from meeting with members of the "industry" and that a reasonable apprehension of bias is not automatically triggered as a result of preliminary discussions or meetings. Clearly a situation where a party whose application for pipeline construction has been granted meets with NEB members to discuss when pipeline construction can commence, would not warrant and should not warrant judicial interference. ${ }^{35}$
\end{abstract}

The Law Reform Commission of Canada has made the following comments regarding the impartiality of board members:

[I]mpartiality requires that no agency member sit in a proceeding in which he is interested, or is perceived to be interested, financially, personally or otherwise. This common law rule against bias or apprehension of bias has been applied for many years to the adjudicative functions of administrative agencies.... In spite of the difficulties of application that are raised because of the ongoing relationships that often develop between agencies and those with whom they deal, the Supreme Court of Canada has emphasized that independent administrative agencies must follow the highest standards of impartiality when performing their responsibilities (see Committee for Justice, [1978] 1 S.C.R. 369). Violation of this rule constitutes a basis for attacking the validity of an agency proceeding on jurisdictional grounds. 
This rule should continue to be followed. It is an appropriate standard to bind independent administrative agencies that exercise statutory decision-making responsibilities. It demands full disclosure by the member, in the context of a proceeding, of any circumstances that could give rise to a reasonable apprehension of bias. Moreover, the member should withdraw unless the participants consent to his continuing to hear the case and he is not otherwise in violation of a conflict-of-interest rule. $^{36}$

Arguably, board members should not meet with industry participants at all, for if they do, an observer viewing the matter impartially would most likely wonder what was being discussed, and a reasonable apprehension of bias would undoubtedly arise. This creates a very difficult situation for regulators who were in essence selected for the very connections with industry which they are now required to avoid. Arising from their many years of experience in the industry will be many close alliances and friendships. However, it is this very closeness which makes it essential that board members take care in meetings with industry actors. The close relations which characterize the energy industry will mean that a reasonable apprehension of bias may arise almost instantaneously upon a board member being seen involved in discussions with a party who regularly appears before the board.

\section{Use of Regulators' Own Specialized and General Knowledge}

Board members may have certain general ideas or predispositions which arise out of their specialized knowledge of the industry. This is only natural. The common law recognizes that such general knowledge will not normally be of a disqualifying nature. However, the moment a member steps outside this general knowledge and acquires a predisposition in a particular case, for example, through contacts with industry, the member acquires a disqualifying bias.

In Newfoundland Telephone Co. v. Newfoundland (Board of Commissioners of Public Utilities) ${ }^{37}$ the Supreme Court of Canada held that comments made by a member of the Newfoundland Board of Commissioners of Public Utilities gave rise to a reasonable apprehension of bias. The board member in question had formerly been a consumer advocate and regularly made clear that he saw his role as that of a promoter of consumer interests. Before the board decision was issued, he made several strong statements to the press about the excessive remuneration of executives of the utility. He and two other board members formed a majority of the board which in its decision disallowed certain remuneration costs of the utility. The Court observed that:

Administrative boards play an increasingly important role in our society. They regulate many aspects of our life, from beginning to end.... In Canada, boards are a way of life. Boards and the functions they fulfil are legion. 
The composition of boards can, and often should, reflect all aspects of society. Members may include the experts who give advice on the technical nature of the operations to be considered by the board, as well as representatives of government and of the community...

[A] consumer advocate who has spoken out on numerous occasions about practices which he, or she, considers unfair to the consumer will be expected to put forward the consumer point of view. Yet that same person will also strive for fairness and a just result. Boards need not be limited solely to experts or bureaucrats. ${ }^{38}$

The Court noted that although a duty of fairness is owed to regulated parties by all administrative bodies, regardless of their function, the extent of that duty varies with the nature of the function and the particular tribunal. Cory J. then continued:

Janisch published a very apt and useful Case Comment on Nfld. Light \& Power Co. v. P.U.C. (Bd.) (1987), 25 Admin. L.R. 196. He observed that Public Utilities Commissioners, unlike judges, do not have to apply abstract legal principles to resolve disputes. As a result, no useful purpose would be served by holding them to a standard of judicial neutrality. In fact to do so might undermine the legislature's goal of regulating utilities since it would encourage the appointment of those who had never been actively involved in the field. This would, Janisch wrote at 198, result in the appointment of "the main line party faithful and bland civil servants"....

This does not of course mean that there are no limits to the conduct of board members... In the end. however, commissioners must base their decision on the evidence which is before them. Although they may draw upon their relevant expertise and their background of knowledge and understanding, this must be applied to the evidence which has been adduced before the board. ${ }^{39}$

The implication of the Newfoundland Telephone decision is that while certain general preconceived ideas and knowledge arising from a board member's experience in the industry are permitted, impartiality must nevertheless be sought. In addition to bias considerations, use of the regulator's own knowledge raises issues of the evidentiary record in a proceeding. The Supreme Court would most likely agree that such knowledge must not form the entire basis of the decision, but may be applied to the evidence adduced before the board. What the case law makes clear is that, while the knowledge of the decision maker may be used to augment that presented as part of a formal record, disclosure of "evidence" is essential to the fairness of the proceedings.

An illustration of these principles is contained in the case of $R$. v. Schiff, ${ }^{40}$ where a very informal hearing was held in connection with a hospital labour dispute. No viva voce evidence was adduced and the proceedings were non-adversarial. The written 
briefs submitted by the parties were comprehensive and far reaching. The board based its award not only upon materials submitted by the parties, but also upon further data it had obtained concerning terms in other collective agreements in the province. It also took into account the Consumer Price Index for the city in which the hospital was located. The parties were not given an opportunity to inspect this extraneous public material or to comment on it. The Court, however, accepted the hospital's argument that the hearing was of such a nature that the parties consented to and invited the board to obtain and examine its own material, data and information. The Court observed that the board had expressed its intention to the parties to seek information of its own volition, and that the material was "from publicly known government sources, and entirely supplemental in its nature and kind to the very material the parties themselves supplied to the board." ${ }^{.41}$

The authorities suggest that when outside evidence not available to the public is relied upon without the parties having notice thereof, the decision will be invalid. Tribunals may rely upon outside evidence, but the parties must be notified that the board is doing so, in order that they may have an opportunity to correct any inaccuracies. If the parties are notified and choose not to controvert the outside evidence, they will be precluded from later attacking the decision on that basis.

The issue of confidentiality of information is often raised in the context of disclosure of specialized knowledge. The recent case of International Woodworkers of America v. Consolidated-Bathurst Packaging Ltd., ${ }^{42}$ suggests that policy matters as distinct from matters of fact need not be disclosed. In this case, a decision of the Ontario Labour Relations Board was upheld by the Supreme Court of Canada as not being offensive to the principles of natural justice. A three-member panel had reached a certain conclusion, but in the course of deliberating over its decision, a meeting of the full board was held to discuss the draft reasons. The board's position changed during this meeting. The Court held that such meetings ensured consistency in the board's decisions, and that there was no pressure on the original panel to reach its decision. Only matters of policy were addressed and no new evidence or arguments were introduced. Had they been, the hearing would have needed to be reopened.

In Tremblay v. Quebec (Commission Des Affaires Sociales), ${ }^{43}$ the result was different. A change in decision after the full meeting of the board was invalidated because the circumstances suggested that, although the meetings were said to be optional, there was in fact great pressure on the original panel to abide by the suggestions given at the full board meeting. A unanimous Supreme Court of Canada held that the compulsory attendance created an appearance of a lack of independence. 


\section{Official Notice}

The concept of official notice is similar to that of judicial notice in the court system. It allows a tribunal to take notice of facts within its experience or common knowledge. ${ }^{44}$ Official notice also allows board members to have regard to matters within their general knowledge of the industry. This does not include matters within the adjudicator's private knowledge. ${ }^{45}$

Official notice is most often used by technically expert board members to supplement or at least clarify evidence which has been formally adduced. ${ }^{46}$ For example, the preamble in board recommendations or decisions may state "having regard to the evidence presented and considered and having regard to their own knowledge and findings herein...." ${ }^{\prime 47}$ To the extent that the board can take judicial notice of facts, methodologies and other matters within its knowledge, efficiency is imported into the hearing process since parties are not required to build the record "from scratch". Official notice may not, however, be used as a method of avoiding the audi alteram partem principle.

Justice McRuer stated that the "extent to which official notice may be taken, and the conditions thereof, are among the most difficult problems in administrative law." ${ }^{48} \mathrm{He}$ described the concept of official notice as follows:

[T]he fair procedure developed by the courts over the centuries requires that all matters in dispute before the courts be decided on the basis of facts proved in evidence adduced by the parties, so that the parties can have an opportunity to meet allegations against them. An exception to this general proposition is that facts of common knowledge may be taken into account in reaching a decision without evidence having been introduced to prove them. If the facts are truly of common knowledge, further proof is not required.

One of the considerations leading to the establishment of administrative tribunals or of specialized judicial tribunals outside the courts is to develop in the tribunals expert knowledge and experience in the fields in which they operate. This is particularly true in relation to scientific or technical matters. In the specialized field in which certain tribunals operate many scientific and technical facts can be accepted. In order to make the best use of such specialized tribunals, and for their efficient operation, it is desirable that they ought not to be restricted in the use of their expert knowledge and experience in reaching decisions.

An example of a fact receiving official notice is the political conditions in Guyana as being a matter within the "common knowledge" of the Immigration Appeal Board: Permaul v. Min. of Employment \& Immigration (1983), 53 N.R. 323 (F.C.A.). Re Frank Bros. Ltd., supra note 11.

C. Hunt, "Alberta" in Canada Energy Law Service, (Scarborough: Carswell, 1993) at 30-3366, para. 705.

Ibid. [emphasis added]. See also Application of Zone Designations No. 151 and no. 187-A to Parts of Township 27, Ranges 15 and 16 West of the 4th Meridian, (28 August 1978), No. 78-16 (ERCB) at 11.

Ontario Royal Commission Inquiry into Civil Rights, Report No. I (Toronto: Queen's Printer, 1968) (Commissioner: Hon. J.C. McRuer) at 169. 
Notwithstanding that specialized tribunals should use their expert knowledge and experience, justice demands that interested parties be permitted to correct any inaccuracy in the use of such knowledge and experience that may adversely affect them. ${ }^{49}$

The right of tribunal members to use specialized knowledge acquired through their adjudication of prior cases was confirmed by the Supreme Court of Canada in La Cité de Ste-Foy v. La Société Immobilière Enic Inc. ${ }^{50}$ In that case, the Régie des services publics was allowed to make a deduction to the value of subdivided land on the basis of its own experience with this type of issue. Abbott J. said:

Comme je l'ai dit, à mon avis et en l'absence de preuve que la Régie trouve satisfaisante, elle était justifiée de faire une déduction pour l'aménagement des services aux lots à subdiviser, etc., basée sur sa propre expérience des questions de ce genre, une expérience qui en fait est considérable.

...Je suis d'avis qu'en conférant cette juridiction arbitrale à la Régie, la Législature a reconnu la qualité d'expert, la compétence et l'expérience particulière des membres qui la composent et voulu l'utilisation, la mise en oeuvre de ces qualification spéciales dans l'exercice de cette juridiction arbitrale.

Des vues similaires paraissent applicables dans les provinces de droit commun. Dans «Russell on Arbitration», $17^{\complement}$ éd., le savant auteur s'en exprime ainsi à la page 183:

Where the parties employ an arbitrator who has expert knowledge, and authorize him to make use of that knowledge, it is of course proper for him to do so; and it would seem that the court will tend to presume such authority from the mere fact of employment of a specially qualified person as arbitrator.

In such a case it will be no objection to an award that the evidence actually tendered by the parties is insufficient to support it, if there are materials upon which the arbitrator himself could have supplied the deficiency. ${ }^{31}$

More recently, in Innisfail (Township) v. Vespra (Township), ${ }^{52}$ the Supreme Court of Canada confirmed this use of a tribunal's past experience. The town of Barrie wanted to annex neighbouring areas and was projecting a population of 25,000 . The issue at the hearing before the Ontario Municipal Board was how much land Barrie would need to accommodate that population. The board stated that it knew from its experience that an industry of the relevant type would require approximately four times the land initially used for expansion, and took official notice of that fact. The decision was challenged on the basis that the board brought in factual matters that should have had an evidential base and been subject to cross-examination. The Court affirmed the Ontario Court of Appeal judgment that the board was able to make decisions based upon its experience in previous cases involving Barrie. It was held that the board used 
previous cases as examples only, not as a compelling precedent. There was therefore no error of law.

In contrast to these two Supreme Court cases is the Alberta Court of Queen's Bench decision in Champlin Canada Ltd. v. Calco Ranches Ltd., ${ }^{53}$ which dealt with a decision of the Alberta Surface Rights Board. In assessing fair compensation for the acquisition of surface rights, the board had relied on information about land values that it had obtained in other hearings. The Surface Rights Board deals with a very large number of cases and it is unlikely that the parties to this proceeding could have been aware of the earlier cases. The Court was of the view that this important and relevant evidence should have been disclosed. No reference to either the Ste-Foy or Innisfail decisions was made.

Perhaps it is possible to reconcile this last case with the Supreme Court decisions by concluding that a tribunal may take official notice of its past decisions and information acquired through earlier deliberations without disclosure to affected parties, except where the information or decision relied on:

(1) is not readily ascertainable (for example, where the tribunal makes a large number of decisions); or

(2) is very specific (such as a per-acre value) rather than general or directional in nature and is applied as direct evidence in reaching the tribunal's conclusion.

A tribunal may apply a methodology or analysis based on its past decision-making experience but, if the tribunal is aware of direct evidence or specific information from prior proceedings which it intends to use, there is an obligation to disclose such information to all affected parties.

\section{Information Generated By Tribunal Staff ${ }^{54}$}

As noted earlier, technical boards are supported by their staffs. Staffs generate studies, prepare summaries of evidence and make recommendations. What limits are placed on the ability of staff to advise members? When, if at all, would a tribunal be obliged to disclose staff-generated information?

The general proposition is that confidentiality of internal documents should be regarded as the exception, not the rule. ${ }^{5 s}$ Access to information is all the more

For further discussion of this topic generally, see R. Franson, Access to Information: Independent Administrative Agencies (Ottawa: Minister of Supply \& Services Canada, 1979) at 28-34; Law Reform Commission of Canada, Independent Administrative Agencies (Working Paper 25) (Ottawa: Minister of Supply \& Services Canada, 1980) at 134-37; H.J. Janisch, "Case Comment: Nfld. Light \& Power v. P.U.C. (Bd.)" (1987) 25 Admin. L.R. 196. 118 (F.C.A.). 
justified in that information allows effective participation and helps participants ensure that the "right" decision is reached. ${ }^{56}$ Case law clearly allows parties access to documents that are in the possession of the agency and on which it intends to rely. ${ }^{57}$ However, in Lucas \& Bell's 1977 study of the NEB, it was observed that board files are regarded as privileged and are not normally available to persons other than board members or staff:

The most difficult problem of access to information concerns studies and reports prepared by NEB staff. These may be intended for internal use and concern general policy matters or a particular application. Detailed reports are normally prepared by staff members on particular applications after the hearing. However, some briefing material is usually prepared and sent to panel members in the course of staff review of the application. All of this material, including studies and reports, is regarded as confidential unless specifically authorized for release by Board decision or tabled by the Minister.

Many lawyers with NEB experience referred to the problem of undisclosed staff studies bearing on particular applications. Oddly, however, the agency has not received a formal written demand with notice to other parties for production and placing in evidence of internal NEB studies or reports. The reason appears to be that many requests for such documents have been satisfied informally, usually before the hearing. When production is refused, industry parties that must deal with the NEB on a continuing basis are probably not likely to press the matter. ${ }^{58}$

Each of the NEB, Alberta Public Utilities Board ("PUB"), and Alberta Energy Resources Conservation Board ("ERCB") is empowered to appoint staff to provide technical support. ${ }^{59}$ It is not entirely clear in law that a tribunal may be compelled to give a party an opportunity to make adequate reply to an internal document prepared by tribunal staff which may contain allegations against his interests. ${ }^{60}$ Advocates of non-disclosure contend that confidentiality of board reports is essential to maintain candor and openness within the agency. In an age of increased privacy awareness, however, the law is arguably moving in the direction of greater openness and accountability. Whether this will yet find its way into the particular context of administrative tribunals is less clear.

Rule 25 of the ERCB Rules of Practice provides that ERCB minutes, accounts and records are admissible when produced by any ERCB member or authorized staff See Re Canadian Radio-Television Commission and re London Cable TV Limited, [1976] 2 F.C. 621 at 625 (F.C.A.).

For example, see Rozander v. Alberta (Energy Resources Conservation Board) (No.2) (1978), 93 D.L.R. (3d) 284, 8 Alta. L.R. (2d) 203 (S.C.A.D.); Re Saskatchewan Telecommunications (1986), 18 Admin. L.R. 171 (S.P.U.R.C.); Magnasonic Canada Limited v. Can. (Anti-Dumping Tribunal), supra note 55.

Supra note 21 at 63 [footnotes omitted].

In relation to the PUB, see the Public Utilities Board Act, R.S.A. 1980, c. P-37, ss. 13-15, and in relation to the NEB, see the National Energy Board Act, R.S.C. 1985, c. N-7, ss. 9-10.

For example, see A. Roman, supra note 19 at 83 . For a discussion of the role that counsel to the tribunal may play, see Omineca Enterprises Lid. v. British Columbia (Minister of Forests), [1994] 2 W.W.R. 422, 85 B.C.L.R. (2d) 85 (C.A.) and Hutterian Brethren Church of Starland v. Starland No. 47 (Municipal District) (1993), 9 Alta. L.R. (3d) 1, 14 Admin. L.R. (2d) 186 (C.A.). 
member. Staff submissions may be filed and presented at hearings where "the Board is of the opinion that it is proper for the applicant to be made aware of the views of the Board's staff."61 No express provisions suggest that participants may compel admission of board materials. Staff submissions have occasionally been made during ERCB hearings, but usually either in board-initiated technical hearings or in inquirytype hearings. ${ }^{62}$ For example, in a 1973 hearing on pressure maintenance by water injection, a staff proposal for basin-wide pressure maintenance was considered and "dismissed" by the ERCB. ${ }^{63}$ In a 1979 sour gas pipeline hearing, an application by an intervener to compel presentation of staff evidence was dismissed. The ERCB stated that it:

will only require a submission from its staff where its staff had special information relating to a matter under consideration which was not otherwise available, and the Board does not believe that such is the case in this instance.

The staff role to date has been that which it normally is; that is, of administering for the Board the handling of an application. ${ }^{64}$

In relation to the obligation of a tribunal to release relevant information, Reid \& David ask:

How is one to know what information the tribunal has in its possession? Is there any obligation on the tribunal to make voluntary disclosure? This may be a ticklish question, for if there is no such obligation, the knowledge that the tribunal has relevant or even prejudicial information may be the result of accident or luck. Without such knowledge however one can hardly complain, or take any step to obtain the information. This is hardly satisfactory. Much can be said for a general requirement that a tribunal make disclosure of relevant information to interested persons if is has been obtained outside any hearing or otherwise beyond their knowledge. Despite its obvious desirability no general rule to this effect has yet emerged. Indeed there are expressions somewhat to the contrary.

On the one hand, it has been held that natural justice requires that all evidence be disclosed to the person whose rights are being decided, and that it is not sufficient that such evidence would be disclosed if requested. On the other hand, that only prejudicial material need be disclosed, but the person must indicate precisely what was not disclosed, and indicate in a general way how he intended to deal with the allegedly prejudicial documents. It is suggested that the latter requirement imposes, in many cases, an unrealistic burden.

61 ERCB Rules of Practice, Alta. Reg. 149/71, as amended by Alta. Reg. 60/83, Rule 27.

62 Hunt, supra note 46, para. 707.

63 Pressure Maintenance by Water Injection in the Amber-Larne-Virgo-Zama Areas (9 January 1973), No. 73-1 (ERCB).

64 Application of Amerada Minerals Corp. of Canada Ltd. for a Secondary Sour Gas Pipeline in the Chestermere-Okotoks Area, ERCB Application No. 780242, transcript at 38. 
The whole question of access to evidence is tied up with the question of how far a tribunal may go in making inquiries on its own, or outside a hearing. This is a vital question to which the answers are vague. If, by statute, a hearing is merely one means of informing a tribunal authorized to make inquiries on its own, there is little force in the argument that all its information must be revealed to interested persons. The question whether a tribunal has such authority may be settled by the governing statute, but it rarely is. [In a footnote, the authors add: Unhappily, such statutes rarely, if ever, state whether information obtained outside the hearing must be disclosed to interested persons.] Other considerations are thus resorted to in determining the question. One of these...is whether the function of the tribunal is administrative or judicial. The state of being one, or the other, is not immutable. A tribunal having an ultimately administrative discretion but which is required to hold a hearing in the process may be required to act judicially in respect of the hearing and permitted to act as it may wish outside it. Does this mean that it must reveal information received from other sources during, or prior to, the hearing? What about information received after the hearing? The courts have had to struggle with this problem and, again, while some points have emerged their general significance is uncertain. Natural justice has been called in aid.... ${ }^{65}$

Arguably, the better position is that if a board fails to disclose relevant staff studies so that participants may respond, its decision is likely to be impeached upon judicial review. ${ }^{66}$ Consistent with this view is Rozander v. Alberta (Energy Resources Conservation Board) (No. 2), ${ }^{67}$ wherein the Alberta Court of Appeal suggested, ${ }^{68}$ without deciding the issue, that a consultant's report on the effects of high voltage electric transmission lines on irrigation farming should have been disclosed to farmer interveners in the hearing on the transmission line application. After commissioning and considering the report, the ERCB approved a different route proposed by the applicant. The interveners were not aware of the report until after the decision was issued.

In Toshiba Corp. v. Anti-Dumping Tribunal, ${ }^{69}$ a board decision relying upon two undisclosed staff reports was upheld. Toshiba applied for review of a decision of the Anti-Dumping Tribunal because of its reliance on two undisclosed staff reports: a preliminary report highlighting the issues for the tribunal and presenting assertions on disputed points of fact, and a second report consisting of a "summary [of] and commentary" on the evidence and submissions made at the inquiry. The Federal Court of Appeal held that the board's failure to disclose the first report was a "dangerous practice" and a "technical breach of the rules of natural justice. ${ }^{70}$ It nevertheless held that it was only a "technical breach of the rules of natural justice" which would not vitiate the decision of the board. The logic was that the result of the inquiry would have been no different had the breach not occurred, since everything in the report was based upon facts and sources which were either matters of general and public knowledge or which were "brought out at the hearing in such a manner that all the parties ... had a at 90-92. 
full opportunity to test them." ${ }^{71}$ With respect to the second report, it was held that while its contents went well beyond a mere summary of evidence presented, there was "nothing improper" and not even a technical breach of the rules of natural justice. The Court also drew an analogy between internal reports and law clerk memos, holding that internal documents need not be disclosed. One commentator has, however, suggested that this is a poor analogy because law clerks are not nearly as influential with judges as are expert staff in technical areas with board members. ${ }^{72}$

A similar result occurred in Trans Quebec \& Maritime Pipeline Inc. v. Canada (National Energy Board). ${ }^{73}$ Trans Quebec \& Maritime Pipeline Inc. ("TQM") had applied for leave to appeal two NEB decisions and have them set aside. It also applied for orders requiring the NEB to file the record of the proceedings under attack along with any staff papers prepared for the board in relation to those proceedings. The Federal Court of Appeal dismissed the application, holding that in the context of applications for leave to appeal and applications to review there is no general right to production of staff papers unless they contain relevant evidence that the parties should have an opportunity to address. It also held that comments and opinions of staff need not be produced in any event, because decision-makers could not necessarily be assumed to have adopted staff comments and opinions. TQM had not shown that the staff opinions constituted additional evidence as opposed to mere comments and suggestions.

H.N. Janisch, in a case comment on both Toshiba Corp. v. Anti-Dumping Tribunal and Trans Quebec \& Maritime Pipeline Inc. v. Canada (National Energy Board), expresses regret that neither decision fully addressed "one of the most urgent issues in contemporary administrative law. ${ }^{174}$

In Radulesco v. Canada (Human Rights Commission), ${ }^{75}$ the Supreme Court of Canada suggested that, at least in a quasi-judicial setting, a certain standard of disclosure is necessary to give real effect to the right to be heard. It was held that in order to ensure that submissions are made on an informed basis, a decision-maker must, prior to its decision, disclose the substance of the case against the party.

The Law Reform Commission of Canada has made the following suggestions on how some of these difficult issues may be approached:

In principle, participants should have reasonable access to all information that is relevant to the decision the agency will make. Disclosure of information leads to a more open administrative process, which yields more accurate and acceptable decisions on the strength of a more informed presentation

Ibid.

H.N. Janisch, "Case Comment: Toshiba Corp. v. Anti-Dumping Tribunal; Trans Quebec \& Maritimes Pipeline Inc. v. National Energy Bd." (1985) 8 Admin. L.R. 188, citing K.C. Davis, Administrative Law Treatise, 2d ed. (San Diego: Davis, 1980).

[1984] 2 F.C. 432, 8 Admin. L.R. 177.

Janisch, supra note 72 at 188.

[1984] 2 S.C.R. 407, 55 N.R. 384. 
and analysis.... An open process contributes to fairness, efficiency and accountability in administrative decision making. Agencies that guard their independence must proceed openly.

We think that information and opinions contained in a staff study that are relevant to a proceeding should be made available to participants, either by allowing access to the study, or by ensuring that the information and opinions are otherwise placed on the record. Administrative law must seek to ensure that there is no "hidden agenda", that the record discloses all essential information and issues and that there is a reasonable "window" on the agency process. We believe that agencies can accommodate themselves to a broad standard of disclosure without any undue impact on staff candour. We doubt that broader disclosure would result in inadequate documentation or "clandestine" briefings. To a great extent the problem is more one of attitude than of substance. Agencies should demand that their staff produce full, frank and accurate reports whether or not they be subject to disclosure. We think that a broadly stated legislative standard favouring disclosure would help to dissipate the lingering reluctance of some to accept the full import of an open administrative process.

Documents prepared by agency staff in the course of the decisional process of the agency should not be subject to disclosure. There is a distinction, albeit a fine one, between studies that are prepared either before or during an administrative proceeding and are aimed at providing agency members with the necessary background to understand the issues that will arise in the course of the proceeding, and memoranda that are developed to assist the agency in coming to its decision. An agency is entitled to professional advice and assistance in fulfilling its decision-making responsibility, and as long as no new information or opinions are introduced, there appears to be nothing more exceptionable in such a practice than in the one that allows judges the assistance of legally qualified clerks or secretaries whose memoranda' are not open to public review. ${ }^{76}$

\section{ARBITRATION}

\section{A. WHAT IS IT?}

\section{Arbitration was defined in the CBA Task Force Report on $A D R$ as:}

A dispute resolution process in which disputants present proofs and arguments to a neutral third party who has the power to hand down a binding decision, generally based on objective standards. ${ }^{n}$

Arbitration is essentially a consensual reference to adjudication outside the civil court process, but the proceeding is often conducted according to judicial rules ${ }^{78}$ and is frequently governed by legislation. ${ }^{79}$ Arbitration is a method of adjudication that

LRCC Report 26, supra note 36 at 57-59 [emphasis in original].

$C B A$ Task Force Report on $A D R$, supra note 1 at 5.

Re Dawdy and Hartcup (1885), 15 Q.B.D. 426, Lord Esher (C.A.).

In Alberta, the legislation is either the Arbitration Act, S.A. 1991, c. A-43.1, or the International Commercial Arbitration Act, S.A. 1986, c. 1-6.6. 
developed out of a widespread and popular dissatisfaction with the cost and delays involved in the administration of justice through the civil courts. Like regulatory adjudication, arbitration stemmed from a desire to have technically complex issues determined by knowledgeable individuals. One view is that an arbitration is essentially a judicial proceeding with the exception that the discretion is exercised by an arbitrator rather than a judge. ${ }^{80}$

While arbitration agreements are infinitely variable, they usually require that the dispute be determined by arbitrators who are qualified by education and training to pass upon the particular questions. Some agreements have express provisions regarding specific qualifications of the arbitrator. ${ }^{81}$ The arbitrator may be required to be a member of a specified trade association or be engaged in a particular trade. ${ }^{82}$ Certain persons may be specifically precluded from arbitrating, such as a person with an interest in a transaction ${ }^{83}$ or a lawyer. ${ }^{84}$ If an appointed arbitrator does not possess the required qualifications, the appointment will be ineffective and any award which has been made will be void. ${ }^{85}$ As with regulatory tribunals, expertise of the arbitrator may be an important reason for the parties choosing the alternative form of dispute resolution.

\section{B. WHAT KNOWLEDGE CAN BE RELIED ON BY ARBITRATORS?}

\section{Arbitrators' Expertise}

The foremost duty of arbitrators, both at common law and under arbitration legislation, is to comply at all times with the principles of natural justice. ${ }^{86}$ St. Boniface School District v. Macdonald is illustrative:

A Board of Arbitration is a judicial body and functions in a judicial way; it must determine its facts and make its findings upon evidence submitted in the presence of the interested parties, or of their representatives. It cannot receive evidence in the absence of the parties, nor from sources unknown to them.... 87

Re Hopper (1867), L.R. 2 Q.B. 367 at 370.

Sir M.J. Mustill \& S.C. Boyd, The Law and Practice of Commercial Arbitration in England, 2d ed. (London: Butterworths, 1989) at 248-49.

For example, see: Oakland Metal Co. Lid. v. D. Benaim \& Co. Lid., [1953] 2 Lloyd's Rep. 192, [1953] 2 Q.B. 261; and The Myron v. Tradax Export, [1970] I Q.B. 527, [1969] 1 Lloyd's Rep. 411.

For example, see Cook International Inc. v. BV Handelmaatschappij Jean Delvaux, [1985] 2 Lloyd's Rep. 225.

For example, see Rahcassi Shipping Co. SA v. Blue Star Line Lid., [1967] 2 Lloyd's Rep. 261 at 264.

Mustill \& Boyd, supra note 81 at 10 . This objection may be waived if the other party continues with the arbitration after the lack of qualifications is known.

St. Boniface School District v. Macdonald, [1927] 2 D.L.R. 735 (Man. K.B.); J.H. Wigmore, Evidence in Trials at Common Law, Vol. 1 (Boston: Little, Brown \& Co., 1983) at 248, para. 4e; Alberta Arbitration Act, supra note 79, s. 19.

Ibid. at 737, Dysart J. 
An arbitrator must therefore always act in good faith, listen fairly to both sides and allow both sides to make submissions. If an arbitral award is reached in violation of these principles, the arbitrator may be found to have "misconducted" himself which will result in the award being set aside. "Misconduct" in this context has a wider meaning that when used in a colloquial sense, denoting irregularity and not moral turpitude. ${ }^{88}$

One reason that the parties may have selected arbitration as a means of dispute resolution is disillusionment with conventional adversarial processes. ${ }^{89}$ If the dispute is one which will essentially be reduced to a duel between experts, the parties may decide to submit their dispute to an arbitrator who possesses some expertise in the field, reasoning that such a reference will alleviate the parties from the necessity of parading expert witnesses before a judge. Instead, they may rely upon the arbitrator to draw upon his expertise, thereby significantly reducing the time and expense involved in obtaining a decision. As was observed by Darling J. in British Oil \& Cake Mills, Ltd. v. Horace Battin \& Co:

The people who go to arbitration desire to have arbitrators or umpires who will not decide on evidence alone, but will bring to the consideration of cases a great deal of special knowledge, and they beyond everything want the matter decided one way or another without delay, so that they can devote all their attention to their business and not to litigation in the Courts. ${ }^{90}$

There are many other statements to similar effect. For example, R. Bernstein \& D. Wood observe, in the second edition of the Handbook of Arbitration Practice, that:

In England and Wales an arbitrator is often appointed because of his expertise in the field in which the dispute arises. He is therefore presumably expected to use this expertise; after all, the parties are paying for it. ${ }^{91}$

Similarly, Mustill \& Boyd note in The Law and Practice of Commercial Arbitration in England, that:

[T]he whole purpose of choosing arbitration for a quality dispute is that the parties can with the minimum of time and expense obtain a decision from someone in whose independence and expertise they have faith. ${ }^{92}$

London Export Corporation Led. v. Jubilee Coffee Roasting Co. Lid., [1958] 2 All E.R. 411 at 413 , [1958] 1 W.L.R. 661 at 665 , Jenkins L.J.

For example, see L. Street, "Practice Note", 66 Aust. L.J. at 862.

(1922), 13 Lloyd's List L.R. 443 at 444 [emphasis added].

(London: Sweet \& Maxwell, 1993) at 240 [emphasis added].

Supra note 81 at 48 . To the same effect, see Jordeson \& Co. v. Stora Koppabergs Bergslags Aktiebolag (1931), 41 Lloyd's List L.R. 201 at 203-04; H.J. Kirsh, "Arbitrating Construction Disputes" and B.J. Thompson, "Commercial Dispute Resolution: A Practical Overview" in D.P. Edmond, ed., Commercial Dispute Resolution: Alternatives to Litigation (Aurora: Canada Law Book, 1989) at 175 and 89 respectively; N.J. Wiener, "Is Arbitration An Answer?" (1982-83) 15 Nat. Res. L. 449. 
The leading case is Mediterranean and Eastern Export Co. v. Fortress Fabrics (Manchester) Ltd., where it was held that an arbitrator appointed for his experience in the textiles industry could assess damages without having evidence before him on quantum. Lord Goddard C.J. stated:

It is well known in the experience of the courts that many trades have their own tribunals of arbitration -the Corn Trade, the Produce Brokers' Association, the Oil and Fat Trades Association are instances - and no one has doubted - certainly not in modem times - that it is open to an arbitrator skilled in the trade to use his own knowledge and experience on many matters, such as quality, without having witnesses called before him. One of the reasons why commercial men like to go to arbitration before arbitrators of this description is because it saves the expense of calling witnesses and having the conflicting views of experts thrashed out and decided on. The parties are content and intend to accept the judgment of a man in their own trade on whose judgment they know they can rely.

It must be taken, I think, that, in fixing the amount that he has, he has acted on his own knowledge and experience. The day has long gone by when the courts looked with jealousy on the jurisdiction of arbitrators. The modern tendency is, in my opinion, more especially in commercial arbitrations, 10 endeavour to uphold awards of the skilled persons that the parties themselves have selected to decide the questions at issue between them. If an arbitrator has acted within the terms of his submission and has not violated any rules of what is so often called natural justice the courts should be slow indeed to set aside his award. ${ }^{93}$

While an arbitrator is expected to draw upon his specialized knowledge to aid him in interpreting the evidence, he must always act impartially and comply with the principles of natural justice. An arbitrator may not use his specialized knowledge to derogate from the evidence of the parties without giving the parties notice of that knowledge, so that they may respond.

\section{As was stated by Lord Denning M.R. in Fox and Fisher v. Wellfair Ltd.:}

[an arbitrator's] function is not to supply evidence...but to adjudicate upon the evidence given before him. He can and should use his special knowledge so as to understand the evidence that is given ... and to appreciate the worth of all that he sees upon a view. But he cannot use his special knowledge - or at any rate he should not use it - so as to provide evidence on behalf of the defendants which they have not chosen to provide for themselves. For then he would be discarding the role of an impartial arbitrator and assuming the role of advocate for the defaulting side. At any rate he should not use his own knowledge to derogate from the evidence of the plaintif's experts - without putting his own knowledge to them and giving them a chance of answering it and showing that his own view is wrong. 
[The arbitrator]... must not throw his own evidence into the scale ... or use his own special knowledge for the benefit of the unrepresented party - at any rate he must not do so without giving the plaintiff's experts a chance of dealing with it - for they may be able to persuade him that his own view is erroneous. ${ }^{94}$

\section{Dunn L.J. added the following words:}

it seems to me that an expert arbitrator should not in effect give evidence to himself without disclosing the evidence on which he relies to the parties, or if only one to that party. He should not act on his private opinion without disclosing it. It is undoubtedly true that an expert arbitrator can use his own expert knowledge. But a distinction is made in the cases between general expert knowledge and knowledge of special facts relevant to the particular case.

If the expert arbitrator, as he may be entitled to do, forms a view of the facts different from that given in the evidence which might produce a contrary result to that which emerges from the evidence, then he should bring that view to the attention of the parties. ${ }^{95}$

In Wetherall v. Harrison, ${ }^{96}$ a decision of a panel of justices was challenged on the basis that one member of the tribunal was also a doctor who had specialized knowledge of circumstances surrounding the background of the case. He informed the other justices of his opinion, with which they agreed. On appeal, the Court held that it was not improper for a specialized member to draw on his experience to interpret the case, provided that he did not use his knowledge as evidence or attempt to persuade the other members of the tribunal to reach a verdict based upon his specialized knowledge. Lord Widgery C.J. stated:

I start with the proposition that it is not improper for a justice who has special knowledge of the circumstances forming the background to a particular case to draw on that special knowledge in interpretation of the evidence which he has heard. I stress that last sentence, because it would be quite wrong if the justice went on, as it were, 10 give evidence to himself in contradiction of that which has been heard in court. He is not there to give evidence to himself, still more is he not there to give evidence to other justices; but that he can employ his basic knowledge in considering, weighing up and assessing the evidence given before the court is I think beyond doubt.

He ... should not be giving evidence himself behind closed doors which is not available to the parties. $^{97}$

O'Connor J. added the following:

[1981] Lloyd's L.R. 514 at 522 (C.A.) [emphasis added].

Ibid. at 528-29 [emphasis added].

Supra note 10.

Ibid. at 778 [emphasis added]. 
I endorse fully what Lord Widgery C.J. has said, but they must not, so to speak, start giving evidence in the case because it offends a number of our rules; above all, it is not in the presence of the parties and is not open to cross-examination. But if that is borne in mind, that the person with specialised knowledge must not give evidence, then it seems to me that it is entirely legitimate for him to express his views that he himself has been helped to form on the evidence in the case and on the issues in the case as a result of his own specialised knowledge and to communicate that to his fellow justices, if he so wishes, always bearing in mind that he must not start substituting what he might have said in evidence, as opposed to using his knowledge to assess the evidence which is available. ${ }^{98}$

One of the few Canadian decisions referring to an arbitrator's expertise is Zaleschuk Pubs Ltd. v. Barop Construction Ltd. ${ }^{99}$ a case in which an arbitrator was appointed to determine rent on a commercial lease. The arbitrator was qualified as an appraiser and had no legal training. At the hearing, the landlord invited the arbitrator to visit the leased premises and to view comparable premises referred to in his evidence. The tenant did not object. Following the hearing, the arbitrator viewed the premises and comparable premises, and delivered an award in favour of the landlord. The tenant applied to set the award aside on the basis of arbitral error in that the arbitrator received evidence by visiting the site in the tenant's absence. Vickers J. held that there was no arbitral error although it would have been better if the arbitrator had advised the parties of his inspection:

The arbitrator in this case was not a statutory tribunal. He was a layperson chosen by the parties because of his particular skills in the field of appraisals. Any person reviewing the process could not fail to ignore the obvious skills of the arbitrator for which he was selected by the parties. They sought an appraiser doubtless because they felt his particular skills would lead to a proper conclusion. In making that observation, 1 do not mean to imply that lay arbitrators are somehow relieved of a responsibility to be fair. But matters must be reviewed in context.

While it might have been better if the arbitrator had advised the parties of his inspection, particularly where the matter was raised in argument, I do not believe, in the context of this arbitration hearing, it can be said there has been any denial of natural justice. The parties were well aware of the arbitrator's field of expertise; Zaleschuk knew the arbitrator was on the premises; and counsel for Barop invited him to inspect the comparables without any complaint from opposing counsel. I conclude there has been no arbitral error. In reaching his decision, the arbitrator founded his conclusion upon the expert evidence of a professional witness called to support Barop. He did not rely on his own appraisal. ${ }^{100}$

While Vickers $\mathrm{J}$. was clearly influenced in his decision by the fact that the arbitrator had specialized knowledge in the field, the decision also appears to be based on a finding that the tenant waived the irregularities by his failure to object. 
It is clear from the cases that an arbitrator's specialized knowledge may only be used to interpret the evidence before him. The arbitrator may not give evidence in contradiction of that which has been adduced by the parties. If an arbitrator relies upon outside evidence in contradiction to that adduced by the parties and without affording the parties an opportunity to respond, he will be guilty of misconduct and the resulting award will be set aside as being contrary to the principles of natural justice. ${ }^{101}$ The decision must be based upon the evidence and arguments presented. ${ }^{102}$

\section{Judicial Notice of Matters Not in Evidence}

The principles of natural justice apply to all arbitrators and may not be waived by agreement of the parties. ${ }^{103}$ This is most likely a codification of the common law, which would presumably hold such a waiver to be void as being contrary to public policy. An arbitrator who relies upon evidence obtained outside the hearing process without affording the parties an opportunity to make submissions on that evidence will be violating the principles of natural justice.

An arbitrator may refer to textbooks or articles in order to inform himself of the general background of the case and to keep apprised of current developments in the area. If he does so, however, he should notify the parties of the relevant passage and give them an opportunity of dealing with it by calling further evidence or making submissions or both. Textbooks and articles should not be relied upon as evidence of matters of fact unless the parties consent to such reliance. ${ }^{104}$ While an argument could be made that it should not be necessary to reveal certain types of sources (for example, those which are generally regarded as accurate and reliable such as government statistics), the better view is that if a specific source is to be relied upon in reaching a particular decision, that source must be made known to the parties.

In Phipson on Evidence, it is stated:

Although, however, judges and juries may, in arriving at decisions, use their general information and that knowledge of the common affairs of life which men of ordinary intelligence possess, they may not, as might juries formerly, act on their own private knowledge or belief regarding the facts of the particular case.

[However] ... where a tribunal is composed of or includes specialists in the field wherein the litigation arises, and that situation is brought about by legislation specifically directed to that end, it may act on

Mediterranean and Eastern Export Co. v. Fortress Fabrics (Manchester), Ltd., supra note 93; Wetherall v. Harrison, supra note 10.

H.J. Kirsh, "Arbitrating Construction Disputes" in Edmond, ed., supra note 92 at 179, quoting R.H. McLaren \& E.E. Palmer, The Law and Practice of Commercial Arbitration (Toronto: Carswell, 1982).

Alberta Arbitration Act, supra note 79, ss. 3, 19.

Bernstein \& Wood, supra note 91 at 247. 
its own knowledge. Thus, the lay members of an industrial tribunal may use their own experience in assessing the evidence given by witnesses. If that leads them to take a different view to that of a witness, the witness should be given an opportunity of dealing with the view of the tribunal; but the tribunal are entitled to prefer their own opinion.

A similar principle applies in the case of arbitrations. Indeed these apparent exceptions to general rule are for the most part more properly regarded as illustrations of the proposition that what is notorious may be the subject of judicial notice. The distinguishing feature is that the specialised composition of the tribunal simply widens the scope of what is notorious.

and:

A wider scope is allowed to judicial notice where a specialist tribunal is dealing with a case falling within its own particular sphere of competence. Thus, where a board of arbitrators is appointed from a particular trade, the arbitrators are "fully entilled" to take judicial notice of facts which are notorious within the trade, even if not to the public at large. This principle is not confined to trade boards, but extends to all arbitrators appointed by the contract because of their qualifications within the field wherein the issues in the arbitration arise. ${ }^{105}$

Natural justice requires an arbitrator to communicate all evidence adverse to a party's position to that party so that the party knows the case to be met. While an arbitrator may not solicit his own evidence without advising the parties of that evidence and allowing them an opportunity to make submissions on the matter, the obligation is merely one of informing the parties, particularly if the arbitrator was selected for his expertise. If the parties are informed of certain information possessed by the arbitrator yet choose not to make submissions upon its accuracy, they will be taken to have waived their right to object to any irregularities in the award.

In Anadarko Petroleum of Canada Ltd. v. Syd Johns Farms Ltd., ${ }^{106}$ an arbitration board was called upon to determine the amount of compensation to be paid for entry, occupation and use of land under the British Columbia Petroleum and Natural Gas Act. ${ }^{107}$ It held a hearing and then reserved its decision. In considering its decision, it took into account a report which had not been introduced into evidence at the hearing and which outlined the policy of the British Columbia government regarding the amount of compensation that the Crown would charge for use of its land. The board set the rate of compensation at $\$ 100$ per acre by following the amounts listed in the report, as it felt that compensation payable to the Crown and to private owners of land should be uniform. Bouck J. set aside the award on the basis that the board was performing a quasi-judicial function and therefore was bound to obey the rules of natural justice. The principles of natural justice were violated by the board when it based its decision upon a report without first offering the parties an opportunity to omitted]. 
respond. Bouck J. commended the board for frankly admitting that it had reviewed the report before arriving at its decision but he added:

I find that although the Board did not intend to act unfairly, the result is that it did not follow the rules of natural justice when it referred to the Land Administration Division Report and used it as a basis for its decision without giving the appellant the opportunity of leading evidence in reply or making submissions on the effect of the report. ${ }^{108}$

Bouck J. cited the headnote in Volkswagen Northern Ltd. v. Board of Industrial Relations and Sheet Metal Workers' International Association Local 271, which stated that:

The reception by a tribunal, exercising judicial or quasi-judicial functions, of additional evidence after the conclusion of a hearing and after counsel representing interested parties have withdrawn, goes to jurisdiction and an order made by the tribunal may be quashed if it appears that the additional evidence had a bearing on the order made. ${ }^{109}$

Of similar effect is Canadian Union of Public Employees (Local 21) and Murray v. Regina (City), ${ }^{110}$ wherein a decision of an arbitration tribunal was quashed on the basis that it referred to outside medical information which had not been disclosed to the parties.

Informing the parties of the case against them and the evidence adverse to their position includes the duty to disclose not only documents but also the views of an arbitrator that have developed and are adverse to the position of a party. For example, in Societé Franco-Tunisienne D'Armement-Tunis v. Government of Ceylon, ${ }^{11}$ an umpire heard arguments and received written statements in connection with a dispute between owners and charterers of a vessel as to the amount of a debt owing. The arbitrator's view of the law involved a radical departure from the cases as presented by the parties and raised complicated issues of law on which adequate submissions had not been made and upon which further evidence might be required. The parties were not sufficiently notified of the arbitrator's views, nor were they given an adequate opportunity to reframe their cases in light of this unexpected development. The Court held that the umpire had misconducted himself because he had not allowed the parties an opportunity to make submissions in regard to this new development in the case.

Similarly, in Saskatchewan v. Ace Asphalt and Maintenance (Products) Ltd. and Reid, ${ }^{112}$ it was held that an arbitrator exceeded his jurisdiction and breached the rules of natural justice when he heard a third issue which had not been included in the arbitration agreement, and upon which the parties were not given an opportunity to make submissions. 


\section{Use of the Knowledge of Others}

An arbitrator may use his specialized knowledge to assess the evidence before him, but in the absence of agreement of the parties he may not confer with the parties or witnesses (expert or otherwise) without both parties being present. The reason for the distinction between an arbitrator being able to rely upon his own knowledge but not the knowledge of other outside experts is simple. If the parties have expressly agreed to engage a specialized arbitrator, they implicitly authorize him to put his expertise to use. The parties have not, however, implicitly authorized the arbitrator to expand his knowledge or expertise by engaging in private discussions with witnesses or either of the parties.

Circumstances can be envisioned which require that the hearing be conducted in the absence of one or both of the parties. For example, the parties may reside great distances apart or there may be great hostility between them. Parties may also agree to a "documentary hearing", whereby the arbitrator renders a decision based solely upon documents and no oral submissions are made. However, unless the parties expressly or implicitly agree otherwise, the general principle is that the arbitrator may only hear evidence in the presence of both parties, who must then be given an opportunity to make submissions. If the parties agree to a less formal procedure whereby the arbitrator is authorized to hear evidence in their absence, then the arbitrator's duty is to inform them of all evidence obtained. ${ }^{113}$

In the leading case of Re Gregson and Armstrong, ${ }^{114}$ an award was set aside on the basis that the arbitrator improperly took information from one party in the absence of the other. After the evidence on both sides had been heard, the arbitrators held a meeting on the tenant's farm in the presence of the tenant but without the knowledge of and in the absence of the landlord. Mathew J. held that:

I think this application must be granted, and the award set aside. Arbitrators are not merely valuers; they have judicial functions to perform. Though intending no injustice they must observe the fundamental rules which govern judicial proceedings. In this case they received information from one party to the arbitration in the absence of the other party. After the evidence had all been heard the arbitrators agreed that a view should take place, and notice be given to the parties. No notice was given to Col. Gregson but notice was given to a principal witness who had appeared on his behalf at the hearing. That was the mistake which the arbitrators made. But even that witness did not attend the meeting for a considerable time after its commencement. Meanwhile the arbitrators had before them the other party to the dispute, and held conference with him for some time. That being so, the arbitrators have undoubtedly taken information from one side in the absence of the other. ${ }^{115}$

An interesting inquiry is how parties can agree to ex parte communication with the arbitrator when the principles of natural justice may not be excluded by contract. (Alberta Arbitration Act, supra note 79, s. 3). 
In Williams v. Roblin, ${ }^{116}$ one of the parties sent letters to two of the arbitrators after an arbitration had been closed. The letters contained statements and arguments in favour of that party's position. The other party was not given a chance to inspect the letters, nor was it given an opportunity to respond to them. In setting the award aside, Richards J. held:

It is of little consequence that the arbitrators should say that they were not influenced by such irregular proceedings. Courts go on the broad ground that it is contrary to natural justice that one party should be heard in the absence of the other, when such absence is not wilful; at all events the opposite party ought to be made aware of the communication so made.... "Neither side can be allowed to use any means of influencing the mind of an arbitrator which are not known to and capable of being met and resisted by the other. As much as possible the arbitrator should decline 10 receive private communications from either litigant respecting the subject matter of the reference. It is a prudent course to make a rule of handing over to the opponent all written statements sent to him by a party, and to take care that no kind of communication, concerning the points under discussion, be made to him without giving information of it to the other side." ... "It is so ordinary a principle in the administration of justice, that no party to a cause can be allowed to use any means whatsoever to influence the mind of the judge, which means are not known to, and capable of being met and resisted by, the other party, that it is impossible for a moment not to see that this was an extremely indiscreet mode of proceeding, to say the very least of it. ${ }^{117}$

In Plenty (Village) v. Gunnlaugson, an arbitrator heard evidence in the absence of one or both parties and the decision was set aside:

In the absence of the specific agreement of the parties that he may do so, the arbitrator was bound to conduct the inquiry in the presence of the parties and their counsel so that all evidence collected would be known to them and they might cross-examine and review any documents received by him.... Where the parties restrict the rights traditionally afforded them in such a process, any agreement doing so must be strictly construed. The respondent does not dispute that the arbitrator proceeded ex parte. The arbitrator erred in doing so. ${ }^{118}$

Of similar effect on the issue of construction of agreements between the parties is Marantz v. Portigal, ${ }^{119}$ a case in which the arbitration submission required a hearing but the parties subsequently agreed orally that they would give evidence separate from each other. They also agreed that the arbitrators could call witnesses as they saw fit, which evidence could be given in the absence of the parties. The arbitrators called witnesses and heard evidence from those witnesses without the parties being present. The Court held that agreements between parties to arbitration proceedings are binding upon them and that the arbitrators must conform to the terms of the submission and any agreement superimposed upon it. Maybank J. stated: 44 U.C.Q.B. 391 (Ont. H.C.). 
The parties' rights being as above set forth it should be noted that the oral agreement in this case was in derogation of the rights of the parties; and since this is so it should be strictly construed. Respondents (as well as the applicants) gave up the right of hearing their opponents testify, their rights to cross-examine their opponents, and certain other rights; they did not give up their right to be informed fully, or at least adequately, of the nature of the charges their opponents, the applicants herein, were bringing against them, particularly and especially the matter of damages which these opponents were claiming. It was the duty of the arbitrators to make sure that the respondents understood what was being claimed and why. The respondents were entitled to present their case and their answer to any statements of and claims by the applicants and this they could not do if they were not fully informed about the charges they had to meet. ${ }^{120}$

In Ward v. McAlpine, ${ }^{121}$ it was held that before proceeding ex parte, the proper course is to give formal notice that the arbitration will proceed peremptorily at a specified time. The arbitrator did not do so, and the award was set aside.

In Race v. Anderson, ${ }^{122}$ one of the parties, after the evidence had been closed, sent an affidavit explaining his evidence to the arbitrator. The affidavit was not received by the arbitrator until after he had written out his views in accordance with which he subsequently made his award. The Court nevertheless set aside the award. Hagarty C.J.O. held that:

[w]e cannot but regard it as unfortunate that the referee did not, before executing his award, communicate to the parties interested, the fact of Hudson's communication, bearing as it did on a vital portion of the inquiry.

No principle is more important to be preserved intact than that which declares that every referee must scrupulously hold the balance evenly between litigant parties, and to hear nothing and know nothing (so far as is possible) urged or presented to him for or against one of the parties in the absence of the other, or without that other having the opportunity of knowing or answering it. ${ }^{123}$

The authorities make clear that an arbitrator must render a decision based upon the evidence before him. He also has an obligation to ensure that all of the evidence before him is known to the parties. The decision-maker must not only disclose evidence adduced by other parties, but also evidence that he has obtained himself. If an arbitrator receives evidence, he must disclose it and allow the parties an opportunity to correct any inaccuracies in it.

Ibid. at 102 [emphasis added].

(1875), 25 U.C.C.P. 119 (Ont. H.C.).

(1886), 14 O.A.R. 213 (Ont. C.A.).

Ibid. at 216 [emphasis added]. Additional authority may be found in Hansen Real Estate Inc. $\mathbf{v}$.

Prince Albert Real Estate Limited, Prince Albert Real Estate Board Inc. and Zatlyn (1987), 57

Sask. R. 24 (Q.B.); Wurz and Wurz v. Gamel Construction Lid. and Busch, [1978] 2 W.W.R. (B.C.S.C.); Re Annable and Annable (1908), 8 W.L.R. 132; Re Snider and Miller Arbitration, [1924] 3 W.W.R. 226 (Alta. C.A.); Kennedy v. Beal (1898), 29 O.R. 599 (D.C.). 


\section{Use of Experts or Counsel}

Where arbitrators are appointed because of their skill and knowledge of the subject matter referred to them and are not required to decide by the hearing of evidence, they may consult other persons when it is necessary that they do so in order to decide the submitted matter, and may adopt the views of the persons consulted as their own. Where the arbitrator has to decide upon the evidence put before him, rather than relying upon his knowledge of the subject matter for the reference, the position is less clear. There does, however, seem to be little doubt that the arbitrator may receive evidence of expert opinions and reports as to questions he has to decide and may found his decision upon them. ${ }^{124}$

The utilization of experts by arbitrators has been specifically provided for in the Alberta Arbitration Act. ${ }^{125}$

The use of an expert brings into play the legal maxim delegatus non potest delegare. In the context of an arbitration, the principle means that the person to whom an office or duty is delegated cannot lawfully delegate that duty to another, unless expressly authorized to do so. In the absence of authorization by the parties, an arbitrator must not delegate his duties. ${ }^{126}$ An exception to the rule is that an arbitrator may delegate the performance of acts of a "ministerial character".

The question of the authority of an arbitrator to obtain legal professional assistance has not been conclusively determined, although it appears that in certain circumstances arbitrators may seek legal advice without the consent of the arbitrating parties. Mustill \& Boyd state:

An arbitrator who is not legally qualified may retain a lawyer to draw up the award, and there is no objection to him taking advice on legal issues in the reference, [unless the parties have specifically appointed a non-legal arbitrator] so long as the decision remains his and not that of the lawyer. It is,

A. Walton \& M. Victoria, Russell on the Law of Arbitration, 20th ed. (London: Stevens \& Sons, 1982) at 229-30.

(1) An arbitral tribunal may appoint an expert to report to it on specific issues.

(2) The expert shall be a person agreed on by the parties and, failing an agreement, shall be determined by the arbitral tribunal.

(3) The remuneration to be paid to the expert shall be paid by the parties in equal portions, subject to the direction of the arbitral tribunal.

(4) The arbitral tribunal may require the parties to give the expert any relevant information or to allow the expert to inspect property or documents.

(5) At the request of a party or of the arbitral tribunal, the expert, after making the report, shall participate in a hearing in which the parties may question the expert and present the testimony of another expert on the subject-matter of the report. 
however, preferable that the parties' consent should first be obtained; and the arbitrator should take care to see that the facts laid before the lawyer for his advice are full and accurate. ${ }^{127}$

The alternative view is that, "as the parties have chosen the arbitrator to decide the dispute, he should consult with no-one else [except of course his fellow arbitrators] before making his decision." ${ }^{128}$

\section{Russell on the Law of Arbitration states:}

As the Privy Council has admitted 'the precise length to which an arbitrator may go in seeking outside advice upon matters of law may be difficult to prescribe in general terms.' It follows that generally speaking an arbitrator should not seek such advice without first securing the consent of the parties. If such consent is not secured, it would seem that he may seek advice:

(1) In the drawing up of the award;

(2) In the conduct of the reference; and

(3) As to the general principles of law governing that class of case, but not (except in the case of a legally qualified arbitrator putting a point of law to a friend) upon the actual questions of law in dispute in the case.

An arbitrator who is appointed to decide upon disputes involving questions of law must make his own decision, and not adopt as his own the decision of some legal advisor. If he cannot proceed without instruction as to the law, he should ask the High Court to determine a preliminary point of law or (if the parties prefer it, as they sometimes do) for the opinion of counsel. ${ }^{129}$

The cases cited in support of the statements in Russell on the Law of Arbitration are not of recent vintage. The decision relating to the statement that legal advice may be sought "as to the general principles of law governing that class of case, but not upon the actual questions of law in dispute in the case" is the 1930 case of Louis Dreyfus \& Co. v. Arunachala Ayya ${ }^{130}$ from the Judicial Committee of the Privy Council. The case involved an arbitration that took place under a submission in a contract upon a claim for damages by the buyer of goods against the seller. The seller contended that the contract had been superseded by a later agreement which contained no arbitration clause. The umpire awarded damages and prefaced his award by stating that he had taken "independent legal opinion" that the later agreement did not override the earlier contract. On appeal, it was argued that there was misconduct on the part of the umpire

Supra note 81 at 360. Cases cited are Behren v. Bremer (1854), 3 C.L.R. 40; Threlfall v. Fanshawe (1850), 19 L.J.Q.B. 334; Rolland v. Cassidy (1888), 13 App. Cas. 770 at 776-77; Proctor v. Williamson (1860), 29 L.J.C.P. 157; Baker v. Cotterill (1849), 18 L.J.Q.B. 345; Giacomo Costa fu Andrea v. British Italian Trading Co. Lid., [1961] 2 Lloyd's Rep. 392; on appeal [1963] 1 Q.B. 201, [1962] 3 W.L.R. 512, [1962] 2 All E.R. 53 (C.A.).

$128 \quad$ Mustill \& Boyd, ibid. at 359.

$129 \quad$ Supra note 124 at $231-32$.

$130 \quad$ (1930), L.R. 58 Ind. App. 381 at 391. 
because he had refused to state a special case and then had taken legal advice upon the question without notice to the seller. The Privy Council held that there was nothing on the face of the award to indicate that the umpire had not himself decided the case (after taking advice upon the general rules of law applying), and that consequently the award was valid and there was no misconduct on the part of the umpire.

A case in which the arbitrator was held to have improperly relied upon legal advice was Ellison and Others v. Bray. ${ }^{131}$ It was agreed by the parties that a case would be referred to arbitration and decided by "gentlemen skilled in engineering" with no counsel attending on either side. The umpire made his award in favour of the plaintiffs, subject to the opinion of his attorney as to the legal effect of a certain agreement and resolution. The Court held that it is clear that an arbitrator or umpire is allowed to consult others if he wishes to inform his own mind but he must not substitute the opinion of another for his own. In this case, the Court found that the award was in essence that of the umpire's attorney, and not the umpire's own, and must therefore be set aside.

In Silbert v. David, the Nova Scotia Supreme Court cited Little, Roberts \& Mitchell v. Newton ${ }^{132}$ which held that:

arbitrators may not delegate their authority to a third arbitrator even though it be to decide a point of law and although the person to whom the decision is left is a lawyer. ${ }^{133}$

Also of interest is the following extract from the course materials published by the Alberta Arbitration \& Mediation Society:

Whether the determination is by means of a three man board or a sole arbitrator, the tribunal will normally act alone without further restriction or assistance. Sometimes the arbitrator may wish to take legal advice and very occasionally he may be subject to the rulings of a legal assessor.

We have noted that the arbitrator can reserve the right to obtain such legal advice as he may require, at the time of his appointment. Should he subsequently exercise this power, he is under no duty to notify the parties as he would be were it not expressly reserved. The power to obtain advice may not be exercised in a way which has the effect of delegating the determination of the differences in the reference to any other party. This obligation is personal to the arbitrator and whatever advice he may consider, the eventual decision must be his own.

Sometimes the parties may have agreed that the arbitrator shall sit with a legal assessor whose role is to adjudicate on any legal points which may arise. The assessor stands in a very different position to a mere advisor, for the arbitrator is bound to act according to his decisions. The opinions of an advisor may be freely rejected.

\footnotetext{
$111 \quad$ (1864), 9 L.T. (N.S.) 730.

1122 Man. \& G. 351, 133 E.R. 781.

133 [1933] 3 D.L.R. 463 at 466 (N.S. S.C.).
} 
An arbitrator should not need technical assistance, since his own appointment will normally be dependant upon the possession of a sufficient expertise in the subject area of the dispute. ${ }^{134}$

\section{SUGGESTED GUIDELINES FOR ADR ADJUDICATORS}

"Specialized knowledge" can be defined as information or experience that an adjudicator brings to the task of dispute resolution. The "specialized knowledge" can be that which is possessed by the adjudicator at the time of his appointment, or that which he acquires during his tenure as a decision-maker. Regulatory tribunals and arbitrators, as well as the parties that seek alternative dispute resolution, can ensure that the adjudicators avoid challenges to their participation in decisions, and challenges to their decisions, by following guidelines suggested by the judicial authorities:

(1) Prior to his appointment to resolve a particular dispute, the past experience and associations of the potential adjudicator should be closely examined to avoid any potential allegations of bias.

(2) Once appointed, the adjudicator should not discuss any matter related to the case with one of the parties in the absence of the other parties.

(3) The adjudicator should not publicize his views of the case through the media, speeches or otherwise.

(4) The adjudicator may take notice of facts within his expert or specialized knowledge, and may use that knowledge to weigh, assess or interpret the evidence, but he may not substitute his knowledge or opinions for the evidence.

(5) The adjudicator may not delegate his decision to others, whether they be tribunal staff, counsel or outside experts.

(6) Any specialized knowledge or opinion of the adjudicator that could affect the decision in the dispute must be disclosed to the parties during the hearing so that any party that may be prejudicially affected by that knowledge or opinion has an opportunity to refute or otherwise respond.

The concept that justice should not only be done but should be seen to be done was set in Canadian jurisprudential stone by the Crowe case. ${ }^{135}$ By following the suggested guidelines, adjudicators involved in alternative dispute resolution, whether they be arbitrators or members of regulatory tribunals, can be comfortable in the belief that their specialized knowledge will be used to enhance the efficiency of the ADR process rather than to provide fodder for judicial review applications. 